\title{
SOCIODEMOGRAPHIC AND BEHAVIORAL PROFILE OF USERS TESTING AND COUNSELING CENTER IN STD/AIDS
}

\author{
PERFIL SOCIODEMOGRÁFICO E COMPORTAMENTAL DOS USUÁRIOS DE \\ CENTRO DE TESTAGEM E ACONSELHAMENTO EM DST/AIDS (CTA)
}

\author{
Flávia da Silva CLAUDIANO ${ }^{1}$; José Cassio de MORAES ${ }^{2}$ \\ 1. School of Medical Sciences of Santa Casa of São Paulo (FCMSCSP), São Paulo, Brazil. fsclaudiano@yahoo.com.br ; 2. School of \\ Medical Sciences of Santa Casa of São Paulo (FCMSCSP), São Paulo, Brazil. jcassiom@uol.com.br
}

\begin{abstract}
Testing and counseling centers (TCCs) for sexually transmitted diseases (STDs) and AIDS carry out serological tests free of charge. The aim of this study was to identify and describe the sociodemographic and behavioral profile of the users at a TCC for STD/AIDS in the city of São Paulo. Descriptive study conducted at the "Henfil Henrique de Souza Filho" TCC. Analyses were performed on 3648 users between January 1 and December 31,2010, by means of data gathered from the information system of the TCC. Out of the total number of users analyzed, $74.7 \%$ were male, $77.6 \%$ were single and the predominant age group was from 18 to 24 years for both sexes. Sexual intercourse was the main form of risk exposure: $9.8 \%$ had had some type of STD over the last 12 months and, out of these, 30.9\% had not had any treatment. Sex workers accounted for 3.7\% of the users and men who had sex with men (MSM) accounted for $43 \%$. Conclusion that the demand for the service came mainly from literate young men, with a large number of MSM. Sexual intercourse was the main means of exposure to situations of risk.
\end{abstract}

KEYWORDS: Sexually transmitted diseases. Acquired immunodeficiency syndrome. Health centers. Syphilis. Hepatitis. São Paulo.

\section{INTRODUCTION}

Acquired immunodeficiency syndrome (AIDS) became a worldwide reality in the 1980s, at a time when healthcare authorities worldwide believed that infectious diseases had come under control through advances in technology and medical knowledge (MARQUES, 2002; BRASIL, 2005). Within only a few years, infection by the HIV virus had become a pandemic that was responsible for thousands of deaths at the end of the 1980s and early 1990s. It diminished the hopes, expectations and quality of life of individuals with HIV and became the main cause of death among adolescents and adults aged 15 to 49 years in many countries, including Brazil (SANTOS et al., 2002).

Today, the epidemic in Brazil is stable and concentrated in certain subgroups that present situations of vulnerability. Over recent years, the frequency of cases among women has increased, and the main forms of transmission of the disease have come to be through unprotected heterosexual intercourse and through intimate contact between individuals, mediated by blood, semen and vaginal fluid (PARKER et al., 2002).

The high number of cases of death due to HIV has given rise to serious consequences for the entire community. In Brazil, it has been estimated that approximately 630,000 people aged between 15 and 24 years are living with HIV (BRASIL, 2002a). Between 1980 and 2010, 241,469 deaths due to AIDS were registered, with higher mortality in the northern, northeastern and southern regions, lower mortality in the southeastern region and a stable situation in the central-western region (BRASIL, 2009; SIGNORINI et al., 2007).

Testing and counseling centers (TCCs) were created in 1988 with the aim of interrupting the HIV transmission chain. Today, they receive individuals and couples or groups, who then await the results from HIV, syphilis and hepatitis tests, until they are referred to and attended at a reference service. TCCs also have the role of supporting people who are living with HIV and people with viral hepatitis, by providing support in relation to treatment adherence and counseling for couples who are both seropositive and those in which one partner is seropositive (BRASIL, 2002b).

The aim of this study was to determine the sociodemographic and behavioral profile of users of a TCC in the city of São Paulo in 2010, and to indicate factors that are associated with contamination by HIV, hepatitis B, hepatitis C and syphilis in this population. These data may contribute towards epidemiological surveillance, thereby enabling preventive actions and health promotion actions among the population. 


\section{MATERIAL AND METHODS}

A descriptive study was conducted at the Henfil TCC, which is located in the central zone of the city of São Paulo, using data gathered between January 1 and December 31, 2010 (no conflict of interest). The sample was obtained from secondary data that were extracted from the Ministry of Health's information system for the TCC, which is fed with data collected during the pre and post-test counseling, after applying a standardized questionnaire, which forms part of the routine of the service. Over the period established, 8610 users were attended and 7899 returned to the service to get the results from the tests. In the present study, 3648 users who fulfilled the inclusion criteria established were attended. The criteria were as follows: users of both sexes who sought the service to undergo HIV tests and/or serological tests for syphilis and viral hepatitis for the first time, whose form was completely filled out and who returned to the TCC to get the results from the serological tests.
The variables selected for the present study were those relating to the sociodemographic and behavioral profile and to the laboratory results, as follows: HIV, measured by investigating antibodies using two positive ELISA tests and confirmed using an indirect immunofluorescence test or the western blot test, or a rapid test; hepatitis B, for which the markers HBsAg and total reactive anti-HBs are used; hepatitis $\mathrm{C}$, for which the parameter is the marker anti-HCV; and syphilis, which is diagnosed by means of VDRL). The data analysis experimental statistical program used for the calculations was " $R$ software".

\section{RESULTS}

Among the 3648 users who formed part of this study, $74.7 \%$ were male. Among the women, $0.8 \%$ were pregnant. For both sexes, the age group that most sought care at the TCC was from 18 to 24 years. For both sexes, the predominant marital status was single $(77.6 \%)$. The schooling level was found to be from 8 to 11 years (Table 1 ).

Table 1. Distribution of users according to sex and demographic characteristics. Henfil TCC, São Paulo, 2010.

\begin{tabular}{|c|c|c|c|c|c|c|}
\hline \multirow[t]{2}{*}{ Characteristic } & \multicolumn{3}{|c|}{ Female } & \multicolumn{3}{|c|}{ Male } \\
\hline & $\mathbf{N}$ & $\%$ & $\mathbf{P}$ & $\mathbf{N}$ & $\%$ & $\mathbf{P}$ \\
\hline Total & 2726 & 100 & & 922 & 100 & \\
\hline
\end{tabular}

\section{Age (years)}

$10 \mid-17$

$18 \mid-24$

32

$25 \mid-30$

703

$31 \mid-39$

700

$40 \mid-49$

695

$50 \mid-59$

$60 \mid-69$

70 and over

\section{2}

25.8

25.7

25.5

12.7

5.9

2.5

0.7

$$
\begin{aligned}
& 0.01 \\
& 0.26 \\
& 0.26 \\
& 0.25 \\
& 0.12 \\
& 0.05 \\
& 0.02
\end{aligned}
$$

0.01

15.4

79.1

0.15

0.79

0.04

0.01

0.00

4.6

0.8

0.1

419
2156
125
23
3

Schooling level (years)

None

10

0.4

0.00

0.02

2

13
249
237
208
135
55
22
3

1.4

27

0.01

0.27

25.7

0.25

22.6

0.22

14.6

0.14

0.05

6

0.02

2.4

0.00

1 to 3

55

2

135
674
87
26
--

$\begin{array}{cc}14.7 & 0.14 \\ 73.1 & 0.73 \\ 9.4 & 0.01 \\ 2.8 & 0.00 \\ -- & \end{array}$

0.14

0.73

0.00 
Sociodemographic and behavioral...

CLAUDIANO, F. S.; MORAES, J. C.

\begin{tabular}{lcccccc}
4 to 7 & 444 & 16.2 & 0.16 & 149 & 16.2 & 0.16 \\
8 to 11 & 1233 & 45.3 & 0.45 & 446 & 48.4 & 0.48 \\
12 and over & 984 & 36.1 & 0.36 & 301 & 32.6 & 0.32 \\
\hline
\end{tabular}

Source: Testing and Counseling Center, São Paulo, 2010. P = Prevalence

Regarding the variable of skin color, $52.5 \%$ of the users were classified as white. The second most frequent category was mixed color $(34.3 \%)$. Regarding the region where the subjects lived,
$33.8 \%$ said that they lived in the central zone of the city, followed by the eastern zone $(19.8 \%)$. Some users reported that they lived in other municipalities $(12.0 \%)$ or in other states $(0.4 \%)$ (Table 2$)$.

Table 2. Distribution of users according to sociodemographic and behavioral characteristics. Henfil TCC, São Paulo, 2010.

\begin{tabular}{|c|c|c|c|}
\hline Variables & $\mathbf{N}$ & $\%$ & $\mathbf{P}$ \\
\hline \multicolumn{4}{|l|}{ Skin color } \\
\hline White & 1914 & 52.5 & 0.52 \\
\hline Mixed & 1252 & 34.3 & \\
\hline Black & 411 & 11.3 & 0.11 \\
\hline East Asian & 62 & 1.7 & 0.01 \\
\hline Indigenous & 9 & 0.2 & 0.0 \\
\hline \multicolumn{4}{|l|}{ Region of residence } \\
\hline Central zone & 1235 & 33.8 & 0.3 \\
\hline Eastern zone & 723 & 19.8 & \\
\hline Southern zone & 529 & 14.5 & \\
\hline Western zone & 404 & 11.1 & 0.11 \\
\hline Northern zone & 269 & 7.4 & 0.07 \\
\hline Other municipalities & 438 & 12.0 & 0.12 \\
\hline Other states & 15 & 0.4 & \\
\hline Street dweller & 22 & 0.6 & \\
\hline Not stated & 13 & 0.4 & 0 . \\
\hline
\end{tabular}

\section{Reason for seeking the service}

Exposure to situations of risk

For knowledge of serological status

Others

\section{Presence of STDs over last 12 months}

Yes

No

\section{Treatment for STDs}

Healthcare service

No type of treatment

Self-medication 
Not stated

Pharmacy
5

4

1.4

1.1

51.7

48.3

1885

0.00

0.00

Use of alcohol or drugs over last 12 months

Yes

No

Source: Testing and Counseling Center, São Paulo, 2010. P = Prevalence

For $57.8 \%$, care was sought from the TCC because of some type of exposure to situations of risk. In second place, it was sought because of knowledge of the serological status $(41.5 \%)$. The way in which the users found out about the service was firstly through publicity material $(39.1 \%)$, and secondly through recommendations from friends or other users $(30.6 \%)$.

In relation to referrals made after the pretest, $93.7 \%$ of the users were referred for or chose to undergo all of the tests offered by the service: testing for $\mathrm{HIV}$, hepatitis $\mathrm{B}$, hepatitis $\mathrm{C}$ and syphilis. The blood bank was sought by $3 \%$ of the users over the last 12 months, with the aim of testing their serological status in order to donate blood.

The presence of some type of STD over the last 12 months was mentioned by $9.8 \%$ of the users studied. Out of this total, $61.2 \%$ said that they had sought some type of healthcare service for treatment and $30.9 \%$ had not undergone any form of treatment. Use of alcohol or drugs over the last 12 months was mentioned by $51.7 \%$ of the users (Table 2 ). The drug most used was marijuana: $10.8 \%$ of the subjects said that they made use of this drug now and then. Use of alcohol now and then was mentioned by $90.5 \%$ of the users.

In relation to sexual behavior with a stable partner, $25.9 \%$ of the users said that they used a condom in all sexual intercourse. However, the great majority of the subjects investigated $(39.6 \%)$ did not make use of condoms (Table 3 ). In relation to the variable of use of a condom during the last intercourse with their stable partner, the majority of both sexes said that they had not done so. Regarding the reason for not using a condom with their stable partner, the most frequent responses were: trusting the partner, negotiating nonuse and believing that the partner did not have HIV.

Condoms were used in sexual intercourse with casual partners on all occasions by $47.6 \%$, while $11.6 \%$ did not use condoms on any occasion (Table 3). Most of the users said that they had used a condom during the last sexual intercourse with a casual partner. Among the reasons given by those who had not used a condom were that there was not enough time/too much lust and the belief that the partner did not have HIV.

Table 3. Distribution of users by sex, according to use of condoms with stable and casual partners. Henfil TCC, São Paulo, 2010.

\begin{tabular}{|c|c|c|c|c|c|c|}
\hline \multirow[b]{2}{*}{ Stable partner } & \multicolumn{2}{|l|}{ Male } & \multicolumn{2}{|c|}{ Female } & \multicolumn{2}{|l|}{ Total } \\
\hline & $\mathbf{N}$ & $\%$ & $\mathbf{N}$ & $\%$ & & $\%$ \\
\hline Used on all occasions & 463 & 26.7 & 166 & 23.9 & 629 & 25.9 \\
\hline Not used & 689 & 39.7 & 274 & 39.5 & 963 & 39.6 \\
\hline Used on less than half of the occasions & 248 & 14.3 & 126 & 18.1 & 374 & 15.4 \\
\hline Used on more than half of the occasions & 335 & 19.2 & 126 & 18.1 & 461 & 18.9 \\
\hline Not stated & 2 & 0.1 & 3 & 0.4 & 5 & 0.2 \\
\hline Casual partner & Male & & Fem & & Total & \\
\hline Used on all occasions & 973 & 46 & 262 & 54.7 & 1235 & 47.6 \\
\hline Not used & 238 & 11.3 & 63 & 13.1 & 301 & 11.6 \\
\hline Used on less than half of the occasions & 166 & 7.8 & 35 & 7.3 & 201 & 7.7 \\
\hline Used on more than half of the occasions & 735 & 34.7 & 116 & 24.3 & 851 & 32.8 \\
\hline Not stated & 5 & 0.2 & 3 & 0.6 & 8 & 0.3 \\
\hline
\end{tabular}

Source: Testing and Counseling Center, São Paulo, 2010. 
The results relating to HIV showed that $6.5 \%$ of the individuals analyzed were reactive ( $8.3 \%$ of the men and $1.3 \%$ of the women). In examinations to investigate hepatitis $\mathrm{B}, 1.0 \%$ were reactive; hepatitis $\mathrm{C}, 1.8 \%$; and syphilis, $6.7 \%$ (Table 4).
Users with reactive results for HIV who were also reactive for syphilis accounted for $1.5 \%$ of the subjects; hepatitis $\mathrm{C}, 0.3 \%$; and hepatitis $\mathrm{B}, 0.1 \%$.

Table 4. Distribution of the results relating to HIV, hepatitis B, hepatitis C and syphilis. Henfil TCC, São Paulo, 2010.

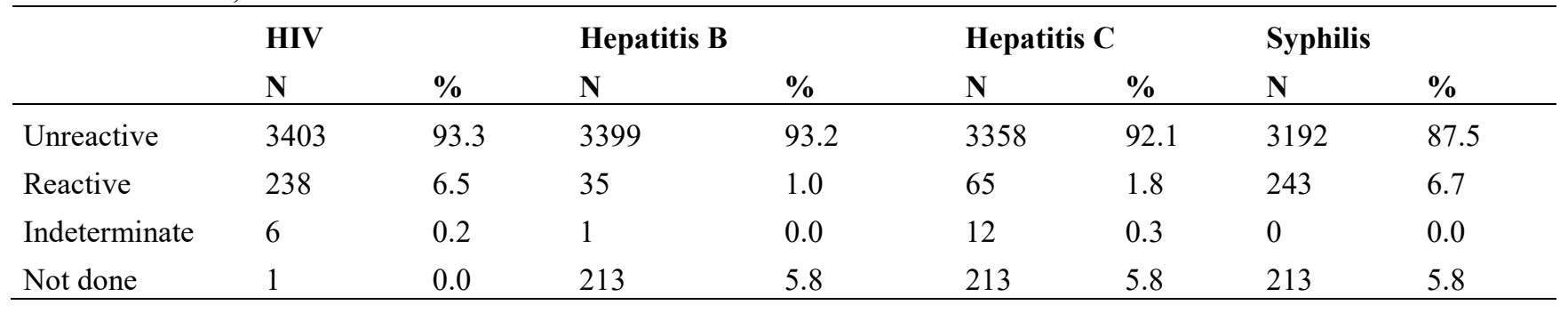

\section{DISCUSSION}

The TCC information system is an important tool for following up the evolution of the prevalences of HIV infection, particularly in populations that are more vulnerable, and for conducting epidemiological surveillance of HIV, through analysis on service users' sociodemographic and behavioral profiles and serological results (SANCHEZ et al., 2002). Through the descriptive analysis of the present study, it was possible to characterize the service user population and gain knowledge of the epidemic at local level.

It was observed that the majority of the users who sought the TCC were young males of reproductive age, with a mean age of 32.4 years. This observation is explained by the greater sexual activity of individuals in this age group. For this reason, they are more exposed to the risk of acquiring STDs.

Both the men and the women predominantly had the marital status of single (77.6\%). The majority of the users had attended school for eight to eleven years, and this was an indication that these users would be able to comprehend information provided during counseling.

Individuals sought the service predominantly because of exposure to situations of risk, and the most important of these was sexual intercourse. A large portion of the population is still exposed to situations of risk, despite educative work developed through public policies warning about the forms of contagion and the preventive mechanisms to be adopted.

Three percent of the users investigated reported that they had made blood donations with the aim of testing their serological status. These users thus revealed that they were concerned about ascertaining their serological status after exposure to situations of vulnerability. Because these individuals probably felt embarrassed about seeking a specialized service for this purpose, they chose to donate blood.

Out of the $9.8 \%$ of the users who responded that they had already had some type of STD over the last 12 months, $30.9 \%$ had not had any treatment. This number can be interpreted as indicating difficulty in accessing healthcare or neglect of personal health, or furthermore, lack of knowledge of the severity of the disease.

In the present study, over the preceding 12 months, $51.7 \%$ of the users investigated declared that they had used some type of drug. Alcohol was used by $90.0 \%$ of the subjects who said that they had used some type of alcohol or drug over the last 12 months. This was perhaps because alcohol is an easily obtained inexpensive licit drug, and its consumption is greatly stimulated through the communication media. For these reasons, many of the individuals investigated used it. When this drug is correlated with STD/AIDS, it can be inferred that they may go hand in hand. For this reason, one way of combating alcohol use, which is an element of vulnerability, would be to develop educative processes in order to deconstruct the false happiness offered through using this drug.

The prevalence of marijuana use was reported as low or high frequency, but the number of people who declared that they were using it did not reflect the reality. On the other hand, it allowed us to infer that the great prejudice against users of illicit drugs causes people to refuse to reply. Because use of marijuana has been criminalized for 
a long time, individuals fear declaring at healthcare services that they are users and dependent on this drug. Marijuana is the most frequently used illicit drug, according to a survey conducted (SILVA; VARGENS, 2009). After marijuana, other illicit drugs are also used, even reaching as far as crack.

The present study found that the use of condoms during sexual intercourse over the preceding 12 months, both with stable and with casual partners, was low. Many reasons for not using condoms were given by the service users, but the main reasons were that they trusted their partner in intercourse with stable partners, and that there was not enough time or too much lust in the intercourse with casual partners. All the reasons given, and those not given, can be interpreted as people's carelessness in the dangerous game and culture of unsafe and irresponsible sexual practices. Such behavior, in reality, is indicative of the lack of a safe-sex culture among the individuals investigated.

In a study conducted it was shown that using a condom in intercourse with stable partners may lead to an uncomfortable situation, which is usually interpreted as mistrust by the partners, or as female infidelity (BRASIL, 2012a).

It was found that $6.5 \%$ of the study population was HIV-positive. Infected men accounted for $8.3 \%$ of the sample and women accounted for $1.3 \%$. The sex ratio of HIV contamination in 2008 was 15 men for every 10 women, and this became 16 men for every 10 women in 2009 (BRASIL, 2012b).

A proportional increase in the number of cases of women affected by the virus has been observed over the years. Thus, the disease is becoming feminized, and this requires that AIDS prevention strategies should take women into account. In 1989, the sex ratio was approximately six AIDS cases in men to only one case in women, and remained thus until 2001. More recently, this ratio has been maintained as 1.6 cases among men to every case in women (BRASIL, 2012b).

The population of young homosexuals has greater vulnerability to HIV infection, and the prevalence of infection among this group went from $0.56 \%$ in 2002 , to $1.2 \%$ in 2007 (BRASIL, 2009). In the present study, $3.7 \%$ of the service users considered themselves to sex workers, of whom $0.9 \%$ were transvestites and $43 \%$ were men who have sex with men (MSM). These data are worrying, since they relate to groups that are vulnerable to acquiring STDs. The AIDS epidemic in Brazil has been characterized as concentrated in groups at higher risk, such that the prevalence in these populations is greater. According to the report from a project on AIDS in the Brazilian National Health Service (SUS), the prevalence of HIV infection among MSM aged 15 to 49 years was $10.5 \%$; among illicit drug users, the prevalence was $5.9 \%$; among female sex workers, it was $4.9 \%$; and in the general population it was $0.4 \%$ among women and $0.8 \%$ among men (BRASIL, 2012b).

\section{CONCLUSIONS}

White men sought the service more than women did. The users were predominantly literate young adults aged 18-24 years, who lived in the central zone of the city.

Users sought the service motivated by exposure to situations of vulnerability, especially through sexual intercourse. STDs were observed in the population investigated, and males were more percentage than females. More than half of the study population mentioned use of alcohol and drugs, and marijuana was the most commonly used illicit drug.

There was low use of condoms, both with stable and with casual partners in relation to the other groups. Many of the service users said that they did not use condoms in sexual intercourse because they trusted their partners or because there was not enough time or too much lust.

The individuals investigated at the Henfil TCC between January 1 and December 31, 2010, who were found to be serologically positive for HIV, hepatitis B, hepatitis C and syphilis, were predominantly young men aged $18-40$ years, due to the higher percentage and prevalence of people in this age group.

\section{ACKNOWLEDGEMENTS}

The authors thank CAPES (Coordination for the Improvement of Higher Education Personnel) for a grant to Flávia da Silva Claudiano.

RESUMO: Os Centros de Testagem e Aconselhamento em DST/AIDS realizam testes sorológicos gratuitos. O objetivo desse estudo foi identificar e descrever o perfil sociodemográfico e comportamental dos usuários de um Centro de Testagem e Aconselhamento em DST/HIV (CTA) da Cidade de São Paulo. O estudo descritivo, realizado no Centro de Testagem e Aconselhamento Henfil Henrique de Souza Filho. Para tanto, foram analisados 3648 usuários, no período de $1^{\circ}$ de janeiro a 31 de dezembro de 2010, através de dados 
coletados pelo programa SI-CTA. Verificou-se que do total de usuários analisados: $74,7 \%$ eram do sexo masculino, faixa etária predominante entre 18 e 24 anos, em ambos os sexos, sendo $77,6 \%$ dos usuários solteiros e a relação sexual foi a principal forma de exposição de risco, dentre eles: $9,8 \%$ tiveram algum tipo de DST nos últimos 12 meses, e dessa porcentagem: 30,9\% não fizeram nenhum tratamento; 3,7\% dos usuários eram profissionais do sexo e $43 \%(\mathrm{HSH})$, homens que fazem sexo com homens. A procura pelo serviço ocorreu principalmente por homens jovens, alfabetizados, grande número de $\mathrm{HSH}$, tendo a relação sexual como principal meio de exposição a situação de risco.

PALAVRAS-CHAVE: Doenças sexualmente transmissíveis. Síndrome da imunodeficiência adquirida. Centros de saúde. Sífilis. Hepatite. São Paulo.

\section{REFERENCES}

MARQUES, M. M. C. C. Saúde e poder: a emergência política da AIDS/HIV no Brasil. História, Ciências, Saúde-Manguinhos, v. 9, p. 41-65, 2002. http://dx.doi.org/10.1590/S0104-59702002000400003.

Brasil. Ministério da Saúde. Guia de Vigilância Epidemiológica. Brasília: Ministério da Saúde; 2005. Available from: http://bvsms.saude.gov.br/bvs/publicacoes/Guia_Vig_Epid_novo2.pdf

SANTOS, N. J. S.; TAYRA, A.; SILVA, S. R.; BUCHALLA, C. M.; LAURENTI, R. A AIDS no Estado de São Paulo: as mudanças no perfil da epidemia e perspectivas da vigilância epidemiológica. Revista Brasileira de Epidemiologia, v. 5, n. 3, p 286-310, 2002. http://dx.doi.org/10.1590/S1415-790X2002000300007.

PARKER, R. G.; GALVÃO, J.; BESSA, M.; PIMENTA, C.; TERTO, V. Anais do Seminário: Conquistas e Desafios na Assistência ao HIV/AIDS. Rio de Janeiro: ABIA. 2002.

Brasil. Ministério da Saúde. Guia para profissionais de Saúde Mental: Sexualidade e DST/AIDS: Discutindo o subjetivo de forma objetiva. Brasília: Ministério da Saúde; 2002a. Available from: http://www.ccs.saude.gov.br/saude_mental/pdf/sexualidade_saude.pdf

SIGNORINI, D. J. H. P.; MONTEIRO, M. C. M.; SÁ, C. A. M.; SION, F. S.; NETO, H. G. L.; LIMA, D. P.; MACHADO, J. D. C. Prevalência da co-infecção HIV-sífilis em um hospital universitário da Cidade do Rio de Janeiro no ano de 2005. Revista da Sociedade Brasileira de Medicina Tropical, v. 40, n. 3, p. 282-285, 2007. https://doi.org/10.1590/S0037-86822007000300006

Brasil. Ministério da Saúde. Boletim Epidemiológico de AIDS, HIV/DST e Hepatites B e C do Município de São Paulo. Ano XIII N.12. Brasília: Ministério da Saúde; 2009. Available from:

http://www.saude.sp.gov.br/resources/crt/vig.epidemiologica/boletim-epidemiologico-crt/boletim2013.pdf

Brasil. Ministério da Saúde. Vigilância do HIV no Brasil novas diretrizes. Brasília (DF); Ministério da Saúde; 2002b. Available from: http://bvsms.saude.gov.br/bvs/publicacoes/162vig_hiv_005.pdf

SANCHEZ, Z. V. D. M.; NAPPO, S. A. Sequência de drogas consumidas por usuários de crack e fatores interferentes. Revista de Saúde Pública, v. 36, n. 4, p. 420-430, 2002. http://dx.doi.org/10.1590/S003489102002000400007

SILVA, C. M.; VARGENS, O. M. C. A percepção de mulheres quanto à vulnerabilidade feminina para contrair DST/HIV. Revista da Escola de Enfermagem da USP, v. 43, n. 2, p. 401-6, 2009.

http://dx.doi.org/10.1590/S0080-62342009000200020

Brasil. Ministério da Saúde. Secretaria de Vigilância em Saúde. Departamento de DST, AIDS e Hepatites Virais. Projeto AIDS-SUS. Relatório de Progresso No 01. Ministério da Saúde; 2012a. Available from: http://bvsms.saude.gov.br/bvs/publicacoes/guia_vigilancia_epidemiologica_7ed.pdf

Brasil. Ministério da Saúde. Boletim Epidemiológico AIDS-DST. Ano VIII N.01. Brasília (DF); Ministério da Saúde; 2012b. Available from: http://bvsms.saude.gov.br/bvs/periodicos/boletim_epidem_hivaids_2012.pdf 